to continue to seek for new facts and new principles in our science, we must strive no less to bring the already well-known and wellestablished facts into the common every-day practice of a much greater number of our people.

President Forkes: As there are two other papers on the list of a similar character, I think we will postpone discussion until after they have been presented. The next paper will be "Entomological Notes from Georgia," by Mr. Worsham.

\title{
INSECTS OF THE YEAR IN GEORGIA
}

\section{By E. L. Worsham, State Entomologist}

This year, as in the past, the board has devoted most of its time to apple, peach, field and garden insects. The insects infesting the peach and apple have been the most important, and much attention has been devoted to these insects. Several new insects have been reported for the first time, as doing considerable damage. The insects which stand at the head of the list from standpoint of damage done are the various scale insects.

The San José scale (Aspidiotus perniciosus) is the most important insect with which we have to deal, though it may be said that it is not feared now nearly so much as it was a few years ago. Its spread over the state is very slow on account of the rigid nursery and orchard inspection maintained by the State Board of Entomology. The lime-sulfur wash is still the leading spray for this scale. In orchards where this wash has been used for four or five years the scale has been greatly reduced and the condition of the orchards much improved. For the past two years the board has conducted experiments with a number of miscible oils. Some gave very good results, but it is yet too early to say how they will succeed in the commercial orchards.

The Cherry Scale (Aspidiotus forbesi) has been found quite numer ous in some cases, though as a rule it does not do a great deal of damage.

Peach Lecanium (Eulecanium nigrofasciatum) has been found in a number of orchards where spraying with lime-sulfur wash was not practised last season:

The Oyster Shell Bark Louse (Mytilaspis pomorum) and the Scrurvy Bark Louse (Chionaspis furfura) were found in a few orchards and on some trees they were quite numerous. The latter was found for the first time on peach trees at Waynesboro. 
The West Indian Peach Scale (Diaspis pentagona) was found to be quite abundant in Augusta. It was found on peach, catalpa and mulberry trees, having almost killed the peach and literally covering the mulberry trees. It was found on almost all of the mulberry trees in the lower part of the city. Steps will be taken this winter to exterminate it before it spreads into the peach orchards. It was thought last season that this seale did not exist in the state, as a search was made where it was present a few years ago, and none found. Just how and when it was introduced into Augusta is not known.

In addition to the above, the following scale insects have been found: Aspidiotus tenebricosus, on poplar trees, Augusta, Ga.; Ceroplastes cirripediformis, on hackberry trees, Augusta; and a species of Kermes quite common on oaks in many parts of the state.

The Gloomy Seale (Aspidiotus obscurus) is very common on oaks and miaples. In some cases it is being kept down by the red headed fungus, but maple trees in Atlanta are being killed by this scale.

Euonymus scale (Chionaspis enonymi) did considerable damage during 1908, killing several hedges in Atlanta and elsewhere.

The White Fly (Aleyrodes citri). was more numerous during the summer than ever before. In South Georgia it was quite common on orange, California privet, umbrella trees and cape jessamine. At Darien it did some damage to the sweet and sour oranges. We have no record of any remedial measures that have thus far been tried.

The Shot-hole Borer (Scolytus rugulosus) was quite common this last summer, and, as in 1905 , was found in some cases to attack trees that, to all appearance, were perfectly sound. At Woodbury $\mathrm{Mr}$. Betts had some badly infested trees, which he saved by painting the trunks and limbs with lime-sulfur wash.

The Peach Tree Borer (Sanninoidea exitiosa) is still a great pest in Georgia. When mounding and worming, together with the application of a caustic wash, is practised, it does but little damage, but-in neglected orchards it injures many trees. This insect is better controlled than it was a few years ago, as many have learned by dear experience that the applications of repellent washes are not effective.

Numerous orchards last fall showed the work of the Peach Twig Borer (Anarsia lineatella), and in some cases they seemed to be doing considerable damage. In old neglected orchards they are most common. In orchards where the lime-sulfurr wash is used they do little damage.

The Plum Curculio (Conotrachelus nemuphar) was not so abundant as in previous years. A few orchards showed bad infestation. In one peach orehard near. Woodbury it destroyed about $50 \%$ of the 
peaches. This orchard had not been ploughed for two years. A few large commercial orchards were sprayed this last spring for curculio, as our experiments in 1907 gave fairly good results. In these experiments we used two pounds of arsenate of lead and three pounds of lime to fifty gallons of water. Where we sprayed twice, $69 \%$ of the fruit was sound; three times, $72 \%$ of the fruit was sound, and where we sprayed four times, $75 \%$ of the fruit was sound. On unsprayed trees there were 13 to $49 \%$ of sound fruit; or on seven unsprayed trees a general average of $30 \%$ sound. In the orchards where experiments were conducted this year there was scarcely any curculio present so we obtained no results. From the work carried on for the last three years, we have decided it is not safe to spray peaches more than twice after blooming, on account of injury to the foliage and fruit.

The Codling Moth (Carpocapsa pomonella) was quite abundant in unsprayed orchards. We have been conducting spraying experiments for control of this insect for the past three years, and the results will soon be published in detail, so we will only mention the work briefly. It now seems that the number of broods varies each year. In 1906 two broods and a part of a third brood were found; in 1907 nearly three complete broods; in 1908 three full and a part of a fourth brood. But it must be remembered that this was an extremely early spring, fruit blooming about ten days earlier than usual, so the Codling Moth has had a long season in which to develop.

In controlling the Codling Moth the best results were secured by spraying, once before the calyx closed, and twice for the second brood. However, very nearly as good results were secured by spraying once before the calyx closed and once for the second brood. One spraying before the calyx closed gave as good results as three sprayings. applied: first, as petals fell; second, before the calyx closed; and third, ten days later. In all of these sprayings we used Disparene, two pounds; bluestone, three pounds; lime, six pounds; water, fifty gallons.

The Woolly Aphis of the apple (Schizoneura lanigera) was present, as usual, in many apple orchards. Some growers are now using the kerosene emulsion for this insect with very good results.

The Green-apple Aphis (Aphis pomi) was quite abundant in a few orchards. We are now advising the use of the tobacco decoction, or $15 \%$ kerosene emulsion for fighting this louse. To beginners in spraying we usually recommend the tobacco decoction as being the least likely to injure the trees.

"The Hessian Fly (Mayetiola destructor) was present in many wheat 
fields, but the infestation as a rule was light and no great amount of damage was done. The board has been working on this insect for several years, and in September a circular was issued giving the results, thus far.secured. From this study it has been found that if wheat is sown from October 20th to 30th, it will not as a rule be damaged to any great extent by the fly.

The Boll Worm (Heliothis obsoleta) was present in many cotton fields, but no great amount of damage reported.

The New Cotton Beetle (Luperodes brunneus) appeared again in June, as it did last year. The first week in July Mr. A. C. Lewis examined some fields where they had been and found that the damage in no case was very great. The beetles first appeared about June 20th, and by July 1st had disappeared. So far, we have had no chance to try poison against this insect.

The Red Spider (Tetranychus gloveri) was present, as it is nearly every year, in several sections of the state. In a field of ten acres near Midville it did considerable damage, and in several other sections of the state great damage was reported. For this insect we recommend dusting with sulfur. Several cotton growers dusted with sulfur and with sulfur and slaked lime, with excellent results.

Specimens of the Striped Cucumber Beetle (Diabrotica vittata), the common potato beetle (Doryphora 10-lineata), and specimens of Harlequin Cabbage Bug (Murgantia histrionica) were frequently received by mail during summer. During summer and early fall we received letters from several parties in South Georgia stating that the mole cricket (Scapteriscus didactylus) was doing a great deal of damage to garden crops. Near Darien one party was using poisoned bran mash to kill these crickets, with fairly good results.

Several times during the summer letters were received from South Georgia stating that a worm was killing cow-peas. The worms ate out the heart of the stem at, or just below, the ground. In one field near Quitman two or three acres were almost completely destroyed. When we visited the fields which they had infested we found that they had disappeared and a careful inspection showed that they had gone into the ground and were found about two or three inches below the surface. It is a lepidopterous larva, but as yet we have not succeeded in getting adults to emerge.

During the summer and early fall much damage was reported from Cabbage Web Worm. A number of truck farmers in South Georgia state that it is impossible to grow cabbage, turnips and other such plants on account of this insect. Remedial measures have not been very succèssful. 
President Forbes: The third paper of the series is "Insects of the Year in Iowa," by Mr. R. L. Webster.

\title{
INSECTS OF THE YEAR IN IOWA
}

\author{
By R. L. Webster, Ames, lowa
}

The following notes on insect injuries in lowa during the past year are taken from office correspondence of Prof. H. E. Summers and from observations of the writer.

- The English grain louse, Macrosiphum granaria, which was so common in Iowa and Minnesota last year, has been hardly noticeable during the past season. Early in the spring it lootrod if this species might again threaten the wheat and oat crop, as it did last year. Winged orms of Macrosiphum granaria appeared in plots of winter wheat at Ames on April 11th. Just where these winged forms came from is unknown. Certainly they did not come from the young nymphs on the wheat, for only the very young progeny of the winged forms themselves were found. Had the species spent the win ter on the grain there should have been some pupæ or older nymphs present. Moreover, the plots had been examined almost daily for several weeks preceding and no traces of aphids of any species had been found. The wind had been in the south for two or three days previous, so it is possible that the insect had been blown in. Were the time later in the spring, a migration from one food plant to another would be probable, but at this time of the season I do not know from what plant the aphid would migrate. Last year I found the winged forms of this species at Albert Lea, Minnesota, May 20th, the first appear ance of the insect in any form in Minnesota that spring. These winged. forms had also apparently only; recently reached the grain from some other situation.

The spring grain aphis, or green bug, Toxoptera graminum, was also scarce in Iowa this year. Not until July 8th were any specimens found, at which time some apterons forms appeared on volunteer oats. These were found along the right of way of the C. \& N. W. Railway, west of Ames: 'What was probably the same species was found at Council-Bluffs on August 6th, but nowhere else in the state. Neither this nor the preceding species were found in southern Iowa in March, when ia thorough search was madë for them in fields of winter wheat. - Ther wheat head army worm, Helionhila albilinea, was very com. mon over the state during: July, espeeially upon timothy. The stalk borer, Papaipema nitela, was also common: during the summer, boring in corn and oats. The clover seed caterpillar, Enarmonia iv- 